\title{
An Economic Removal of Ni(II) from Aqueous Solutions Using an Indige- nous Adsorbent
}

\author{
R.S. Singh ${ }^{1}$, V.K. Singh ${ }^{1}$, P.N. Tiwari ${ }^{2}$, U.N. $\operatorname{Singh}^{3}$ and Y.C. Sharma ${ }^{*}, 4$ \\ ${ }^{I}$ Department of Chemistry, K.N. Govt. P.G. College, Gyanpur, S.R.N., Bhadohi (U.P.), India, ${ }^{2}$ Department of Chemical \\ Engineering and Technology, ${ }^{3}$ Department of Applied Physics, ${ }^{4}$ Department of Applied Chemistry, Institute of Technol- \\ ogy, B.H.U., Varanasi (U.P.), India
}

\begin{abstract}
Carbon slurry, dried in open air, has been used as an adsorbent material for the removal of nickel(II) from aqueous solutions at different experimental conditions in batch adsorption technique. The time required to attain equilibrium was found to be 50 minutes. The effects of initial concentration of $\mathrm{Ni}(\mathrm{II})$, particle size of adsorbent, adsorbent dose, temperature and $\mathrm{pH}$ on removal of nickel(II) have been studied. The removal was favored at higher $\mathrm{pH}$, the $\mathrm{pH}$ value for maximum adsorption being 10.00. Batch adsorption kinetics has been described by the Lagergren equation. Langmuir and Freundlich isotherms were applied and both isotherms were seen to be applicable over the concentration range studied. Thermodynamic parameters indicate the endothermic nature of $\mathrm{Ni}(\mathrm{II})$ adsorption on carbon slurry.
\end{abstract}

Key Words: Adsorption, carbon slurry, isotherms, nickel(II), Thermodynamic parameters.

\section{INTRODUCTION}

In present day context water pollution is the biggest hazard for all forms of life. The environmental pollution has been the most remarkable side effect of rapid industrialization and growing population of the world. Today, almost all the things, which are most necessary to the human beings are more or less contaminated by toxic substances. Industries discharge waste water containing various pollutants such as heavy metals organic and inorganic impurities including colouring materials etc. depending on type of industries, raw materials and processing conditions used. The major Indian rivers are polluted due to the input of various types of wastes from different sources. Thus, it is a compelling necessity for the environmentalists to develop appropriate way to check the deterioration of the environment.

Nickel is $24^{\text {th }}$ most abundant metal in earths crust. Its ores are basically of two types viz. sulphides and oxides. It is usedin electroplating, and in a number of alloys and it is a well known catalyst also. Nickel is recognized as a micronutrient for micro-organisms and animals but not to plants. It is associated with the synthesis of vitamin $\mathrm{B}_{12}$ but has been reported to be toxic at higher concentrations. In animals the toxic effect of $\mathrm{Ni}$ includes dermatitis "nickel-itch" and causes respiratory disorders. Out of all the compounds of nickel, nickel carbonyl is most toxic. It is a carcinogen and a half an hour are to $30 \mathrm{ppm}$ of this compound is lethal to humans. Nickel(II) is present in the effluents of silver refineries, electroplating, zinc based casting and storage battery industries [1]. In India the acceptable limit of nickel in drinking water is $0.01 \mathrm{mg} \mathrm{dm}^{-3}$ and for discharge of industrial wastewater [2] it is $2.0 \mathrm{mg} \mathrm{dm}^{-3}$. At higher concentrations,

*Address correspondence to this author at the Department of Applied Chemistry, Institute of Technology, B.H.U., Varanasi (U.P.), India; Tel: +91 5426702865; Fax: +915422306428; E-mail: ysharma.apc@itbhu.ac.in
nickel(II) causes cancer of lungs, nose and bone. Dermatitis (nickel itch) is the most frequent effect of exposure to nickel objects, such as coins and costume jewelry.

The effective technologies available for the removal of metallic pollutants from water and wastewater include chemical precipitation, ion exchange, solvent extraction, reverse osmosis and adsorption [3]. Adsorption has been a very effective and economical method for removal, recovery and recycling of metals from wastewater [4]. Different conventional and non-conventional adsorbents such as red mud, coconut coirpith, sewage sludge, silica, tree fern, bone char, polymetallic sea nodule, fly ash, maple saw dust, activated carbon, modified zeolites and parthenium plant [5-20] etc. have been cited in the literature as adsorbents by several workers.

The present communication has been addressed to the removal of nickel from aqueous solutions by using carbon slurry. Batch adsorption technique has been adopted in removal and the effect of various important parameters viz. contact time and initial concentration, $\mathrm{pH}$, adsorbent particle size, and temperature on removal of nickel has been discussed. The dynamics of adsorption and isotherm has also been reported. Thermodynamic parameters free energy, enthalpy, and entropy change have also been studied.

\section{MATERIALS AND METHOD}

\section{Materials}

Carbon slurry was collected from the Fertilizer Corporation of India, Gorakhpur, U.P., India and was used as an adsorbent without any pretreatment after passing through sieves to maintain desired particle sizes. Carbon slurry is generated from the scrubbers of the gasification section of ammonia plant operating on oxidation of naphtha. The particle size was measured by B.S.S. sieve size. The bulk density was measured using a specific gravity bottle at room tem- 
Table 1. Analysis of Carbon

\begin{tabular}{|c|c|}
\hline Moisture (\%) & 17.37 \\
\hline Volatile matter (\%) & 24.90 \\
\hline Ash content (\%) & 2.56 \\
\hline Silica (\%) & 2.48 \\
\hline Bulk density $\left(\mathrm{g} \mathrm{cm}^{-3}\right)$ & 0.238 \\
\hline
\end{tabular}

perature. The physico-chemical characterization of carbon is shown in Tables 1-3. All the chemicals used, were of analytical reagent grade. The solutions were prepared using deionised water. Standard hydrochloric acid and sodium hydroxide solutions were used for adjusting $\mathrm{pH}$ of the solutions.

\section{Method}

Batch adsorption experiments were carried out by shaking $1.0 \mathrm{~g}$ of desired grade carbon with $50 \mathrm{ml}$ of nickel solution of known concentration in a $250 \mathrm{ml}$ conical flask placed in a thermostat provided with a shaking machine, at different temperatures, $\mathrm{pH}$ and at an agitation speed of $125 \mathrm{rpm}$. The flasks were removed after the desired contact time and the filtrates were analyzed for the remaining nickel (II) concentration. A systronics 166, Sr. No. 984 (Systronics, Naroda, Ahmedabad, India) spectrophotometer was employed. Dimethylglyoxime procedure [21] was used for the analysis.

\section{RESULTS AND DISCUSSION}

\section{Characterization of the Adsorbent}

The characterization of the adsorbent was carried out and has been presented in Tables 1-3. Table 1 shows analysis of carbon and it can be seen from this table that its ash content is $2.56 \%$ only. Other parameters have also been reported in this table. IR spectra of the adsorbent was also carried out and this provides important information regarding the adsorbent. Band positions show that it has $\mathrm{C}=\mathrm{C}-\mathrm{H}$ stretching, $\mathrm{C}=\mathrm{O}$ stretching, $\mathrm{C}=\mathrm{C}$ stretching, $\mathrm{Si}=\mathrm{O}$ stretching and aromatic ring and $\mathrm{C}-\mathrm{H}$ deforming. $\mathrm{d}$ values at 3.35, 2.08, 2.03, 1.54 and $1.22 \AA$ indicate the presence of carbon(hexagonal system) and that present at 3.34,4.26 and $1.82 \AA$ show presence of silica(quartz low) in the adsorbent. The characterization of the adsorbent shows that these species would be responsible for removal of $\mathrm{Ni}$ (II) from aqueous solutions.

\section{Effect of Contact Time and Initial Concentration}

The transfer of $\mathrm{Ni}$ (II) by adsorption on carbon increases with time and attains a maximum value at $50 \mathrm{~min}$ and thereafter remains constant. On changing the initial concentration of nickel sulphate solution from $22.0 \mathrm{mg} \mathrm{l}^{-1}$ to $278.00 \mathrm{mg} \mathrm{l}^{-1}$ (Fig. 1), whereas the amount adsorbed increases from 1.0319 $\mathrm{mg} \mathrm{g}^{-1}$ (93.81\% removal) to $6.6498 \mathrm{mg} \mathrm{g}^{-1}$ (47.84\% removal) at $25 \pm 0.5^{\circ} \mathrm{C}, \mathrm{pH} 10.00$, particle size $150 \mathrm{~B}$.S.S. It is clear from Fig. (1) that with a lower initial concentration of adsorbate the amount of adsorbate attained on the solid phase is smaller than the amount attained on adsorbent when higher initial adsorbate concentrations are used. Although the percent removal was greater with lower initial concentration than with higher initial concentrations. The equilibrium was

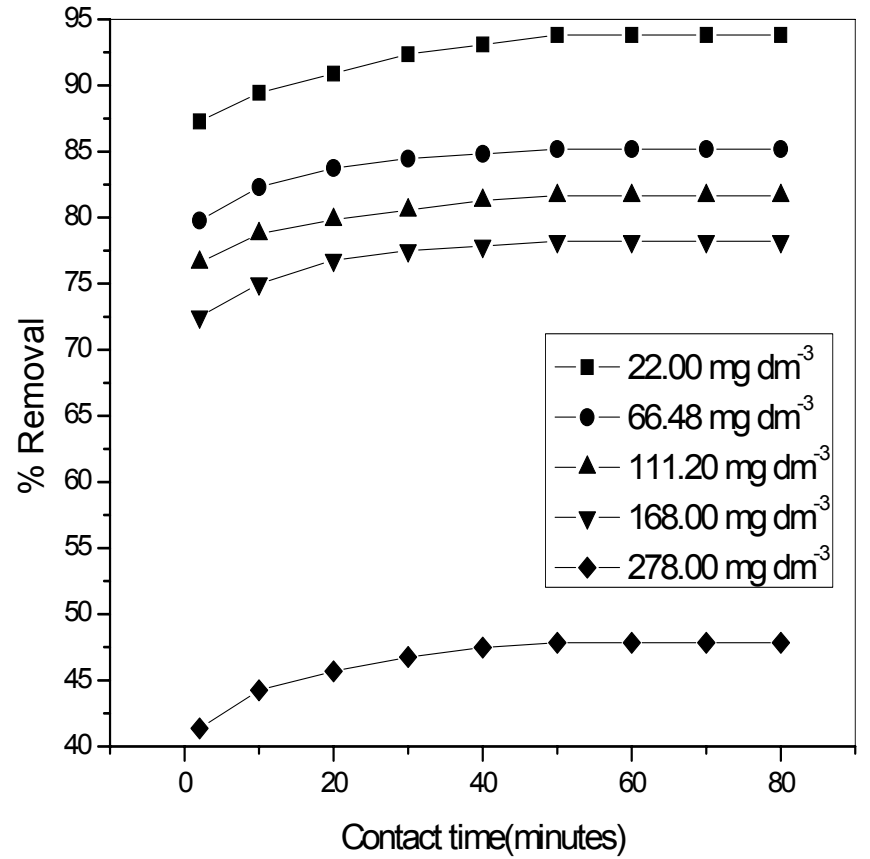

Fig. (1). Time variation of adsorption of Nickel(II) on carbon at different initial concentrations. $[\mathrm{pH}: 10.00$, particle size : 150 B.S.S., temperature: $25 \pm 0.5^{\circ} \mathrm{C}$, agitation speed : $125 \mathrm{rpm}$ ].

established in 50 minutes and was independent of $\mathrm{Ni}$ (II) concentration in water. Similar results have been reported by other workers for other adsorbate-adsorbent system [22-24]. When the adsorbent dose was increased from $4 \mathrm{~g} \mathrm{l}^{-1}$ to $36 \mathrm{~g} \mathrm{l}^{-1}$, complete removal of $\mathrm{Ni}$ (II) took place at initial concentration of $22.00 \mathrm{mg} \mathrm{l}^{-1}$. The curves of Fig. (1) are clear, continuous, single and smooth indicating formation of a monolayer of adsorbate on the adsorbent surface. The higher \% removal of nickel in lower concentration ranges has industrial application as in most of the effluents the lower concentration of nickel is encountered.

\section{Effect of pH}

The uptake of $\mathrm{Ni}(\mathrm{II})$ by carbon as a function of $\mathrm{pH}$ at initial concentration of $22.00 \mathrm{mg} \mathrm{l}^{-1}, 66.48 \mathrm{mg} \mathrm{l}^{-1}, 111.20 \mathrm{mg} \mathrm{l}^{-1}$, $168.00 \mathrm{mg} \mathrm{l}^{-1}$ and $278.00 \mathrm{mg} \mathrm{l}^{-1}$ at temperature $25 \pm 0.5^{\circ} \mathrm{C}$, contact time $50 \mathrm{~min}$, adsorbent particle size 150 B.S.S. and agitation speed of $125 \mathrm{rpm}$ is shown in Fig. (2). The $\mathrm{pH}$ range studied in each case was from 2.00 to 11.00 . It is clear from the figure that for each initial concentration, value of $\mathrm{Ni}(\mathrm{II})$ the percent removal increases as $\mathrm{pH}$ rises and after $\mathrm{pH}$ 10.00 , the percent removal decreases with further increase in $\mathrm{pH}$ value. With initial concentration of $22.00 \mathrm{mg} \mathrm{l}^{-1}$, percent removal at $\mathrm{pH} 2.00$ is $0.0999 \mathrm{mg} \mathrm{g}^{-1}$ (9.09\% removal), at $\mathrm{pH}$ 10.00 it is $1.0319 \mathrm{mg} \mathrm{g}^{-1}(93.81 \%$ removal $)$ and at $\mathrm{pH} 11.00$ it is $1.0280 \mathrm{mg} \mathrm{g}^{-1}(93.45 \%$ removal). Similar with initial concentration of $278.00 \mathrm{mg} \mathrm{l}^{-1}$, the percent removal at $\mathrm{pH}$ 2.00 is $0.6491 \mathrm{mg} \mathrm{g}^{-1}$ (4.67\% removal), at $\mathrm{pH} 10.00$ it is $6.6498 \mathrm{mg} \mathrm{g}^{-1}$ (47.84\% removal) and at $\mathrm{pH} 11.00$ percent removal again decreases upto $6.0993 \mathrm{mg} \mathrm{g}^{-1}(43.88 \%$ removal). This clearly shows that the optimum $\mathrm{pH}$ for the present adsorbate-adsorbent system is around 10.00. Analysis of the filtrate made it clear that at $\mathrm{pH} 10.0$ it did not contain any precipitated form of nickel. Almost similar trends were observed for other values of initial concentration. 
Table 2. Important Infra-red Bands of Carbon Along with their Probable Assignments

\begin{tabular}{|c|c|}
\hline Band Position $\left(\mathbf{c m}^{-1}\right)$ & Assignment \\
\hline $2924.35,2849.12$ & C=C-H stretching \\
\hline 1749.59 & C=O stretching \\
\hline 1647.36 & C=C stretching \\
\hline $1558.62,1591.26,1521.97,1508.49$ & Aromatic ring \\
\hline $1419.74,1396.59$ & C-H deforming \\
\hline $1159.32,1122.67,773.52,518.90$, & Si-O stretching \\
418.59 & \\
\hline
\end{tabular}

Table 3. 'd' Values of Carbon (X-ray Diffraction Pattern)

\begin{tabular}{|c|c|}
\hline $\mathbf{d}\left(\mathbf{A}^{\mathbf{0}}\right)$ & Possible Components \\
\hline \hline 3.35 & Carbon (hexagonal system) \\
\hline 2.08 & Carbon (hexagonal system) \\
\hline 2.03 & Carbon (hexagonal system) \\
\hline 1.54 & Carbon (hexagonal system) \\
\hline 1.22 & Carbon (hexagonal system) \\
\hline 3.34 & Silica (quartz low) \\
\hline 4.26 & Silica (quartz low) \\
\hline 1.82 & Silica (quartz low) \\
\hline
\end{tabular}

It is clear from experimental data that removal increases slowly and than acquires a maxima in $120 \mathrm{~min}$. Uptake of nickel is rapid in initial stages and in later stages it becomes steady. It is expected that the metal competes with protons for surface sites:

$\mathrm{S}-\mathrm{OH}+\mathrm{Ni}^{2+} \leftrightarrow \mathrm{S}-\mathrm{O}-\mathrm{Ni}^{2+}+\mathrm{H}^{+}$

Where ' $\mathrm{S}$ ' stands for surface. In equation it seems that during adsorption one proton is replaced by one nickel atom. Some amount of surface precipitation at the maximum removal of nickel at around 8.0 can also not be ruled out. At $\mathrm{pH}>8.0$, the $\mathrm{Ni}(\mathrm{II})$ ions get precipitated due to hydroxide anions forming a nickel hydroxide precipitate [21].

\section{Effect of Particle Size}

The removal of Ni(II) was found to increase from 2.7437 $\mathrm{mg} \mathrm{g}^{-1}\left(82.54 \%\right.$ removal) to $2.9128 \mathrm{mg} \mathrm{g}^{-1}$ (87.63\% removal) at $\mathrm{pH} 10.00$, temperature $25 \pm 0.5^{\circ} \mathrm{C}$, initial adsorbate concentration $66.48 \mathrm{mg} \mathrm{l}^{-1}$ and agitation speed of $125 \mathrm{rpm}$ as the adsorbent particle size was decreased from 50 B.S.S. to 300 B.S.S. (Fig. 3). B.S.S. stands for British Sieve Standards. The higher adsorption with smaller adsorbate particles may be attributed to the fact that smaller particles provide a larger surface area. The equilibrium time was found to remain unaffected by the change in adsorbent particle size. The other textural characteristics of the adsorbent have been presented elsewhere [22].

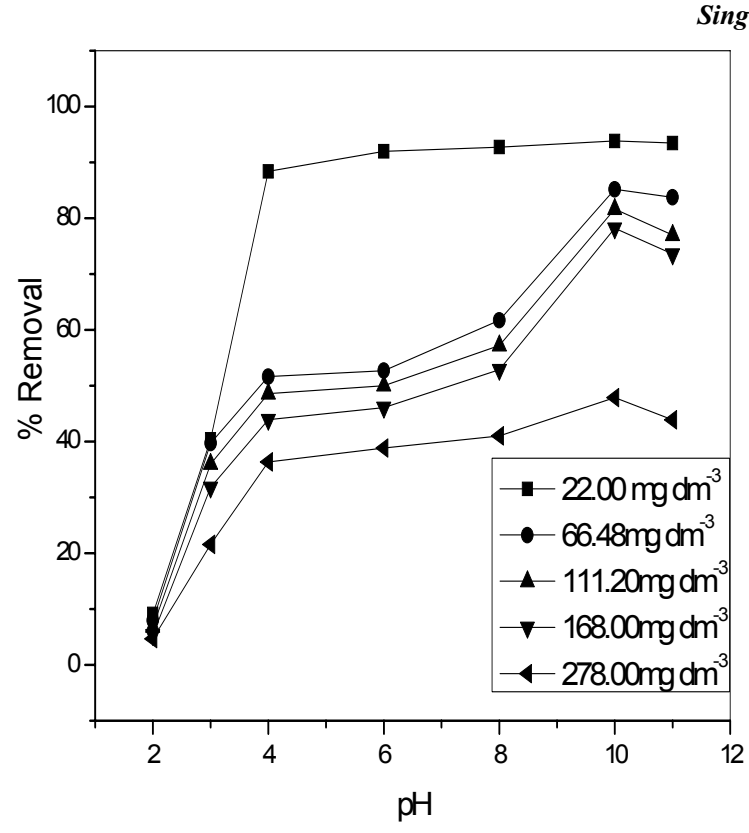

Fig. (2). Equilibrium adsorption of Nickel(II) on carbon at different $\mathrm{pH}$ values. [particle size : 150 B.S.S., temperature: $25 \pm 0.5^{\circ} \mathrm{C}$, agitation speed : $125 \mathrm{rpm}$, contact time : 90 minutes].

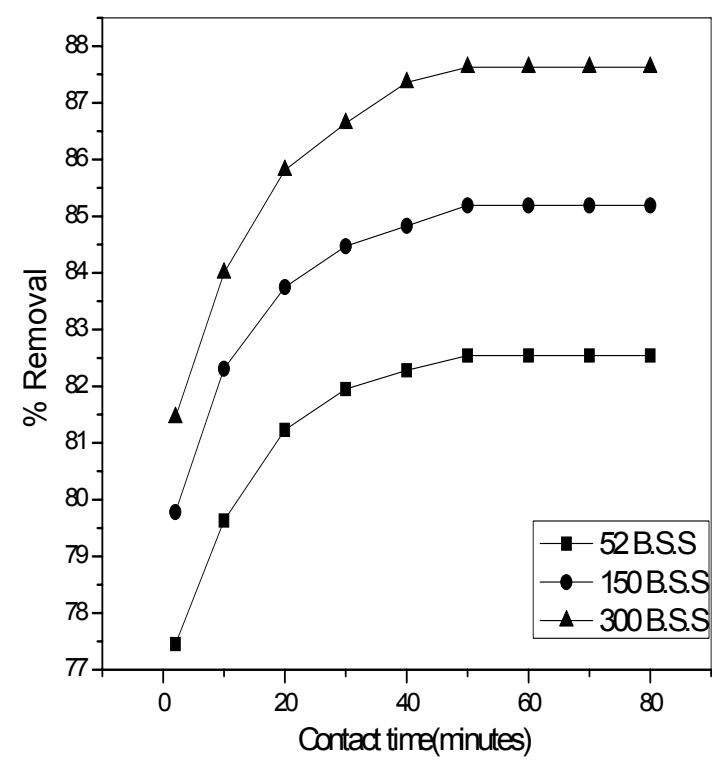

Fig. (3). Time variation of adsorption of Nickel(II) on carbon at different particle sizes. [initial concentration : $66.48 \mathrm{mg} \mathrm{dm}^{-3}, \mathrm{pH}$ : 10.00 , temperature: $25 \pm 0.5^{\circ} \mathrm{C}$, agitation speed : $\left.125 \mathrm{rpm}\right]$.

\section{Effect of Temperature}

The adsorption of $\mathrm{Ni}(\mathrm{II})$ was found to increase from $6.5697 \mathrm{mg} \mathrm{g}^{-1}$ (78.21\% removal) to $7.1098 \mathrm{mg} \mathrm{g}^{-1}(84.64 \%$ removal) as the temperature increased from $25 \pm 0.5^{\circ} \mathrm{C}$ to 75 $\pm 0.5^{\circ} \mathrm{C}$ at $\mathrm{pH} 10.00$, initial adsorbate concentration 168.00 $\mathrm{mg} \mathrm{dm}{ }^{-3}$, particle size 150 B.S.S., agitation speed $125 \mathrm{rpm}$ (Fig. 4). Increase in percent removal of $\mathrm{Ni}(\mathrm{II})$ with increase in temperature indicates the process to be endothermic.

\section{Adsorption Dynamics}

Adsorption dynamics gives idea about solute uptake rate which controls the residence time of solute at the solidsolution interface. Thus, study of adsorption dynamics be- 


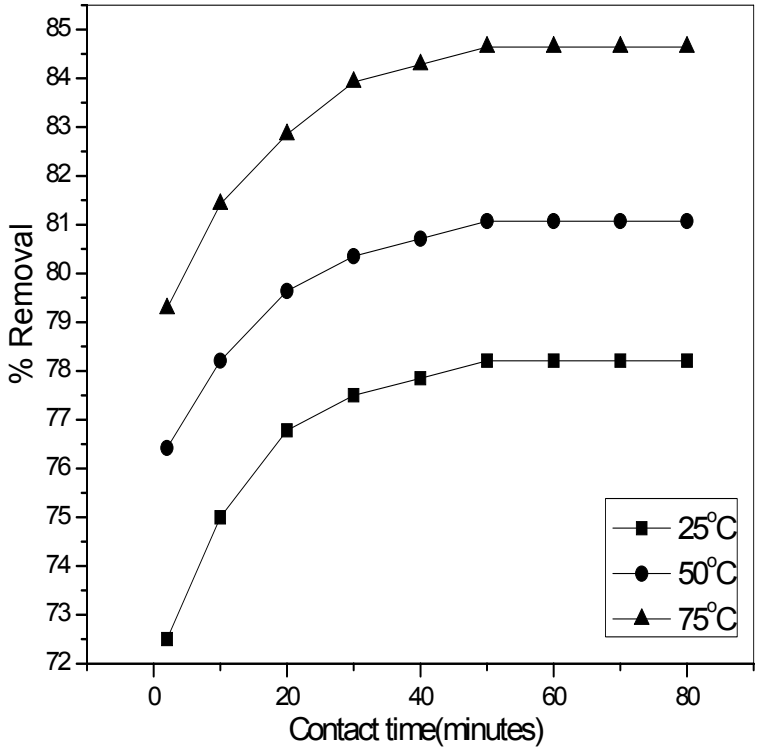

Fig. (4). Time variation of adsorption of Nickel(II) on carbon at different temperatures. [initial concentration : $168.00 \mathrm{mg} \mathrm{dm}^{-3}, \mathrm{pH}$ :10.00, particle size : 150 B.S.S., agitation speed : $125 \mathrm{rpm}]$.

comes quite significant in waste water treatment. This study was done by conducting the batch adsorption of $\mathrm{Ni}(\mathrm{II})$ on carbon in a shaking water bath operated at a fixed agitation speed with different particle sizes of adsorbent, at desired temperatures as given in experimental method. A kinetic model, developed by using the Lagergren equation [25], was used which is as follows:

$$
\log (q e-q)=\log q e-\frac{k^{\prime} t}{2.303}
$$

where qe is the amount of solute adsorbed at equilibrium per unit weight of adsorbent $\left(\mathrm{mg} \mathrm{g}^{-1}\right)$, q the amount of solute adsorbed at any time $\mathrm{t}\left(\mathrm{mg} \mathrm{g}^{-1}\right)$, and $\mathrm{k}^{\prime}$ the adsorption constant. The plots of log (qe-q) versus t (Fig. 5) at different concentrations of $\mathrm{Ni}$ (II) viz. $22.00,66.48,111.20,168.00$ and $278.00 \mathrm{mg} \mathrm{l}^{-1}$ are linear at $25 \pm 0.5^{\circ} \mathrm{C}$ and $\mathrm{pH} 10.00$, agitation speed of $125 \mathrm{rpm}$. A straight line is obtained for each value of initial concentration, indicating that the adsorption follows the above equation used for kinetic modelling. The slope of this plot gives the value of the adsorption constant $\mathrm{k}^{\prime}$. The values of $\mathrm{k}^{\prime}$ for all the initial concentration values are similar i.e. independent initial concentration of adsorbate indicating that the system follows first order rate kinetics (Table 4).

\section{Adsorption Isotherms}

The equilibrium data for the adsorption of $\mathrm{Ni}$ (II) on to carbon at various temperatures and at $\mathrm{pH} 10.00$ follows the rearranged Langmuir equation [26]:

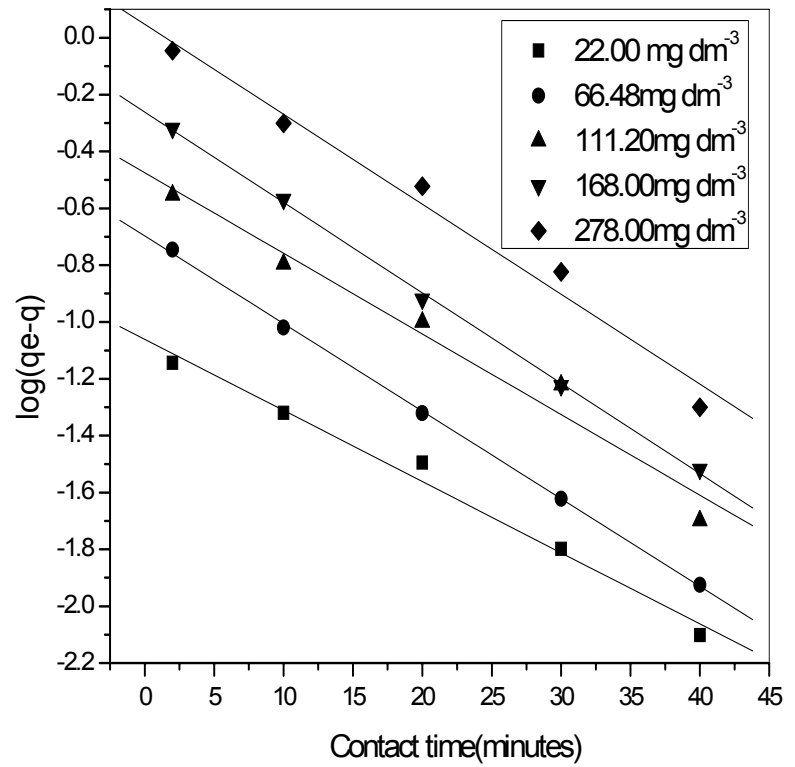

Fig. (5). Rate constant plot for adsorption of Nickel(II) on carbon at different initial concentrations. [pH :10.00, particle size: 150 B.S.S., temperature: $25 \pm 0.5^{\circ} \mathrm{C}$, agitation speed : $125 \mathrm{rpm}$ ].

$$
\frac{\mathrm{Ce}}{\mathrm{qe}}=\frac{1}{\mathrm{Q}^{\mathrm{o}} \mathrm{b}}+\frac{\mathrm{Ce}}{\mathrm{Q}^{\mathrm{o}}}
$$

were $\mathrm{Ce}$ is the equilibrium concentration $\left(\mathrm{mg} \mathrm{l}^{-1}\right)$ and qe the amount adsorbed at equilibrium $\left(\mathrm{mg} \mathrm{g}^{-1}\right)$. The values of Langmuir constants $\mathrm{Q}^{\circ}$ and $\mathrm{b}$, which are related to adsorption capacity and apparent heat change respectively, were determined at different temperatures (Table 5) from the slopes and intercepts of the linear plot of Ce/qe versus Ce (Fig. 6). Further, the plots of figure 6 are single and smooth. This nature of the plots indicates fitness of Langmuir's model for the present system.

As figure 6 indicates, for given values of initial concentration, $\mathrm{pH}$ and particle size of adsorbent, the equilibrium concentration $\mathrm{Ce}$, of adsorbate in solution decreases with increasing temperatures, i.e., the adsorption is favoured at higher temperatures. This is supported from the value of adsorption capacity and apparent heat change Langmuir constants $\left(\mathrm{Q}^{\mathrm{o}}\right.$ and $\left.\mathrm{b}\right)$ which inecrease with increasing temperature (Table 5). The applicability of the Langmuir isotherm in the present system indicates the monolayer coverage of $\mathrm{Ni}(\mathrm{II})$ on the outer surface of the carbon.

The equilibrium data for the present adosrbate-adosrbent system were analysed using Freundlich adsorption isotherm also. The general form of the Freudlich equation is as follows [27]:

$\mathrm{qe}=\mathrm{K}_{\mathrm{F}} \mathrm{Ce}^{1 / \mathrm{n}}$

Table 4. Rate Constant at Different Initial Concentrations (pH : 10.0 , Temperature : $25 \pm 0.5^{\circ} \mathrm{C}$, Particle size : 150 B.S.S.)

\begin{tabular}{|c|c|c|c|c|c|}
\hline Concentration $\left(\mathbf{m g ~ d m}^{-3}\right)$ & 22.00 & 66.48 & 111.20 & 168.00 & 278.00 \\
\hline Rate constant $\left(\mathbf{m i n}^{-1}\right) \times \mathbf{~ 1 0}$ & 5.83 & 7.32 & 6.70 & 7.30 & 7.53 \\
\hline
\end{tabular}


Table 5. Various Constants at Different Temperatures (pH : 10.00, Particle Size: 150 B.S.S., Contact Time: 90 minutes, Agitation speed: $125 \mathrm{rpm}$ )

\begin{tabular}{|c|c|c|c|}
\hline Parameters & \multicolumn{3}{|c|}{ Values at Different Temperature } \\
\hline $\begin{array}{c}\mathrm{Kc}\left(\mathrm{dm}^{3} \mathrm{~g}^{-1}\right) \\
\Delta \mathrm{G}\left(\mathrm{kJ} \mathrm{mol}^{-1}\right)\end{array}$ & $\begin{array}{l}0.4737 \\
0.4425\end{array}$ & $\begin{array}{l}0.7576 \\
0.1782\end{array}$ & $\begin{array}{c}1.4749 \\
-0.2688\end{array}$ \\
\hline
\end{tabular}

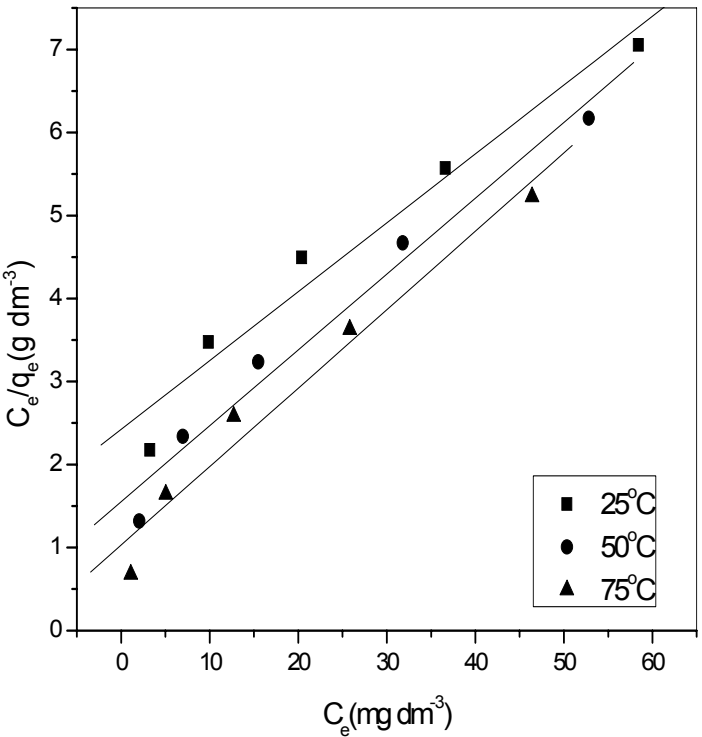

Fig. (6). Langmuir isotherm for the adsorption of Nickel(II) on carbon at different temperatures. $[\mathrm{pH}: 10.00$, particle size : 150 B.S.S., agitation speed : $125 \mathrm{rpm}$, contact time : 90 minutes].

where $K_{\mathrm{F}}$ and $\mathrm{n}$ are constants.

The logarithmic form of the equation is

$\log \mathrm{qe}=\log \mathrm{K}_{\mathrm{F}}+1 / \mathrm{n} \log \mathrm{Ce}$

The plot of $\log$ qe versus log Ce gives a straight line, whose slope (equal to $1 / \mathrm{n}$ ) is roughly an indicator of sorption intensity and the intercept (equal to $\log \mathrm{K}_{\mathrm{F}}$ ) is indicator of sorption capacity. The straight line obtained (Fig. 7) indicate applicability of this isotherm as well for the concentration range studied. Values of $\mathrm{K}_{\mathrm{F}}$ and $\mathrm{n}$ (Table 5) also indicate that the amount of adsorbate adsorbed per gram of adsorbent increases solution temperature which, further, proves the endothermic nature of the adsorption in the present adsorbate-adsorbent system.

\section{Thermodynamic Parameters}

Thermodynamic parameters e.g. $\Delta \mathrm{G}$, the free energy change and $\Delta \mathrm{H}$, the enthalpy change were calculated from the following equations [28]:

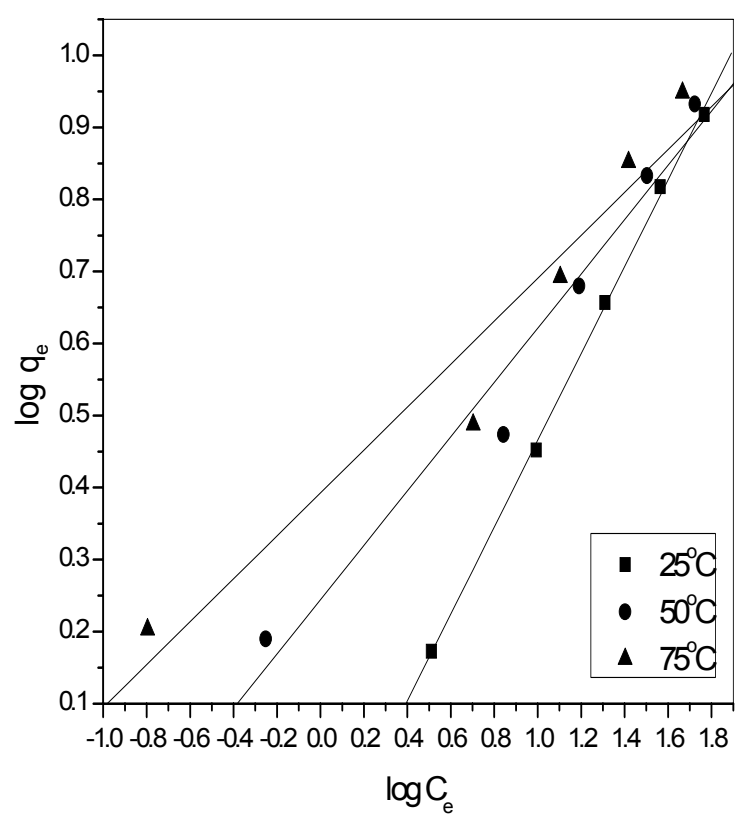

Fig. (7). Freundlich isotherm for the adsorption of Nickel(II) on carbon at different temperatures. [pH :10.00, particle size: 150 B.S.S., agitation speed : $125 \mathrm{rpm}$, contact time : 90 minutes].

$\Delta \mathrm{G}=-\mathrm{RT} \ln \mathrm{K}_{\mathrm{c}}$

and $\quad b=b^{\prime} e^{-\Delta H / R T}$

where $K_{c}$ is equilibrium constant and can be given by

$\mathrm{K}_{\mathrm{c}}=\frac{\mathrm{C}_{\mathrm{Be}}}{\mathrm{C}_{\mathrm{Ae}}}$

$\mathrm{C}_{\mathrm{Be}}$ is the equilibrium concentration of $\mathrm{Ni}(\mathrm{II})$ on the adsorbent $\left(\mathrm{mg} \mathrm{g}^{-1}\right)$,

$\mathrm{C}_{\mathrm{Ae}}$ the equilibrium concentration of $\mathrm{Ni}(\mathrm{II})$ in solution (mg $\left.1^{-1}\right)$.

$\mathrm{T}$ is absolute temperature and $\mathrm{R}$ is gas constant, $\mathrm{b}$ is Langmuir constant while b' is another constant.

Equation (6) can also be written as 


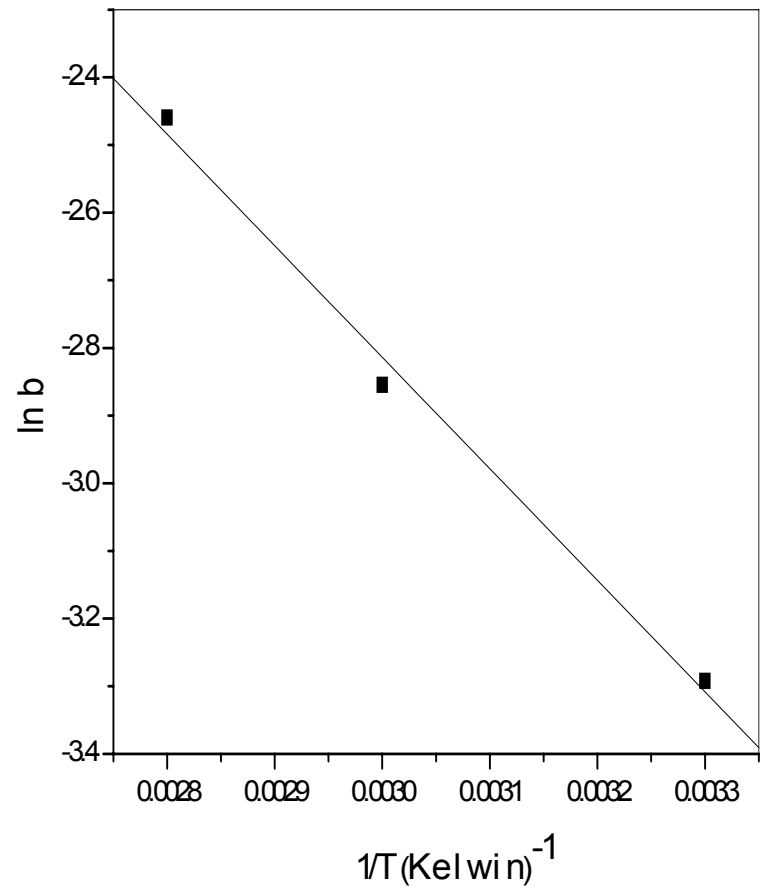

Fig. (8). Plot of $\ln b$ versus $1 / T$ for enthalpy change for the adsorption of Nickel(II) on carbon at different temperatures. [pH :10.00, particle size: 150 B.S.S., agitation speed : $125 \mathrm{rpm}$, contact time : 90 minutes].

$\ln \mathrm{b}=\ln \mathrm{b}^{\prime}-\frac{\Delta \mathrm{H}}{\mathrm{RT}}$

Value of $\Delta \mathrm{H}$ was calculated from the slope of straight line obtained from the plot between $\ln b$ versus $1 / T$ (Fig. 8) and it was found to be $3.3839 \mathrm{KJ} \mathrm{mol}^{-1}$. Positive value of $\Delta \mathrm{H}$ indicates that the process is endothermic. The value of $\Delta \mathrm{G}$ has been found to decrease with rise in temperature (Table 5) and it becomes negative at $75 \pm 0.5^{\circ} \mathrm{C}$ which is indicative of the fact that the adsorption process becomes more spontaneous higher temperature. Both the thermodynamic parameters support the endothermic nature of the adsorption process in the present case of study.

\section{CONCLUSION}

Carbon slurry, the waste product of naphtha based fertilizer plants, can be used as an effective adsorbent material for bringing the $\mathrm{Ni}$ (II) concentration in waste water to acceptable limits by maintaining the optimum conditions of $\mathrm{pH}$, temperature and adsorbent dose. The data obtained in the study, can safely be used by environmentalists to devise pilot plants for abatement of $\mathrm{Ni}$ (II) concentration from waste waters. Using carbon slurry the adsorbent material.

\section{ACKNOWLEDGEMENT}

The authors are thankful to the department of Chemical Engineering, Ceramic Engineering and Mining Engineering of Banaras Hindu University, Varanasi, U.P., India for providing help in characterisation of the adsorbent material.

\section{REFERENCES}

[1] K. Kodirvelu, B. Brasquet and P. Lecloirec, "Removal of $\mathrm{Cu}(\mathrm{II})$, $\mathrm{Pb}(\mathrm{II})$ and $\mathrm{Ni}(\mathrm{II})$ by adsorption onto activated carbon cloth," Langmuir, vol. 16, pp. 8404-8409, 2000.
[2] K. Kadirvelu, Preparation and characterisation of activated carbon from coirpith and its utilization in treatment of metal bearing wastewater, Ph.D. thesis, Bharathiar University. Coimbatore, Tamil, Nadu, India, 1998.

[3] V.K. Gupta, C.K. Jain, I. Ali, M. Sharma and V.K. Saini, "Removal of cadmium and nickel from a wastewater using bagasse flyash-a sugar industry waste," Water Res., vol. 37, pp. 4038-4045, 2003

[4] T. Mathialagan and T. Viraraghavan, "Adsorption of cadmium from aqueous solution by perlite," J. Hazard. Mater., vol. 94, pp. 291-297, 2002

[5] V.K. Gupta, M. Gupta and S. Sharma, "Process development for the removal of lead and chromium from aqueous solutions using redmud-an aluminium industry waste," Water Res., vol. 35, pp. 1125-1131, 2001.

[6] K. Kadirvelu and C. Namasivayam, "Activated carbon from coconut coirpith as metal adsorbent: adsorption of $\mathrm{Cd}(\mathrm{II})$ from aqueous solution," Adv. Environ. Res., vol. 7, pp. 471-477, 2003.

[7] S.C. Pan, C.C. Lin and D.H. Tseng, "Reusing sewage sludge ash as adsorbent for copper removal from wastewater," Resour. Conserv. Recycl., vol. 39, pp. 79-87, 2003.

[8] N. Chiron, R. Guilet and E. Deydier, "Adsorption of $\mathrm{Cu}(\mathrm{II})$ and $\mathrm{Pb}$ (II) onto a grafted silica: isotherms and kinetic models," Water Res., vol. 37, pp. 3079-3087, 2003.

[9] Y.S. Ho, "Removal of copper ions from aqueous solution by tree fern," Water Res., vol. 37, pp. 2323-2336, 2003.

[10] D.C.K. Ko, C.W. Cheung, K.K.H. Choy, J.F. Porter and G. Mckay, "Sorption equilibria of metal ions bone char," Chemosphere, vol. 54, pp. 273-281, 2004.

[11] S. Maity, S. Chakravarty, S. Bhattarjee and B.C. Roy, "A study on arsenic adsorption on polymetallic sea nodule in aqueous medium," Water Res., vol. 39, pp. 2579-2587, 2005.

[12] B. Bayat, "Comparative study of adsorption properties of Turkish fly ashes. II. The case of chromium (VI) and cadmium (II)," $J$. Hazard. Mater., vol. 95, pp. 275-282, 2002.

[13] V.K. Gupta and I. Ali, "Removal of lead and chromium from wastewater using bagasse fly ash a suger industry waste," $J$. Colloid. Interface Sci., vol. 271, pp. 321-329, 2004.

[14] L.J. Yu, S.S. Shukla, K.L. Dorris, A. Shukla and J.L. Margrave, "Adsorption of chromium from aqueous solutions by maple saw dust," J. Hazard. Mater., vol. 100, pp. 53-59, 2003.

[15] S.K. Srivastava, V.K. Gupta and D. Mohan, "Kinetic parameters for the removal of lead and chromium from wastewater using activated carbon developed from fertilizer waste material," Environ. Modell. Assess., vol. 1, pp. 281-287, 1996.

[16] U. Wingenfelder, B. Nowack, G. Furrer and R. Schulin, "Adsorption of $\mathrm{Pb}$ and $\mathrm{Cd}$ by amine-modified zeolite," Water Res., vol. 39, 3287-3292, 2005.

[17] K. Kadirvelu, K. Thamaraiselvi and C. Namasivayam, "Adsorption of $\mathrm{Ni}$ (II) from aqueous solution onto activated carbon prepared from coirpith," Sep. Purif. Technol., vol. 24, pp. 497-505, 2001.

[18] V.K. Singh and P.N. Tiwari, "Removal and Recovery of chromium (VI) from industrial waste water," J. Chem. Tech. Biotechnol., vol. 69, pp. 376-382, 1997.

[19] C.H. Weng, "Removal of Nickel(II) from dilute aqueous solution by sludge-ash," J. Environ. Eng. ASCE, vol. 128, pp. 716-722. 2002.

[20] G.C. Panda, S.K. Das, T.S. Bandopadhyay and A.K. Guha, "Adsorption of nickel on husk of Lathyrus sativus: behavior and binding mechanism," Colloid Surf. B. Biointerf., vol. 57, pp. 135-142, 2007.

[21] Standard Methods for the Examination of Water and Wastewater, APHA, AWWA, WPCF, $14^{\text {th }}$ ed. Washington, D.C., pp. 232-233, 1975.

[22] R.S. Singh, V.K. Singh, U.N. Singh, A.K. Mishra, P.N. Tiwari and Y.C. Sharma, "A novel material for the removal of $\mathrm{Cr}(\mathrm{VI})$ from aqueous solutions and wastewaters," Appl. Sci. Environ. Sanit., vol. 3, pp. E129-E141, 2008.

[23] A.K. Singh, D.P. Singh, K.K. Pandey and V.N. Singh, "ollastonite as adsorbent for removal of $\mathrm{Fe}(\mathrm{II})$ from water," J. Chem. Tech. Biotechnol., vol. 42, pp. 39-49, 1988.

[24] Y.C. Sharma, Uma, S.N. Singh, Paras and F. Gode, "Fly ash for the $\mathrm{Mn}(\mathrm{II})$ from aqueous solutions and wastewaters," Chem. Engg. J., vol. 132, pp. 319-323, 2007. 
[25] Y.C. Sharma, Uma, V. Srivastava, J. Srivastava and M. Mahto, "Reclamation of $\mathrm{Cr}(\mathrm{VI})$ rich water and wastewater by wollastonite," Chem. Engg. J., vol. 127, pp. 151-156, 2007.

[26] Y.C. Sharma, G. Prasad and D.C. Rupainwar, "Treatment of cadmium(II) rich effluents(Kinetic modeling and mass transfer)," Int. J. Environ. Anal. Chem., vol. 45, pp. 11-18, 1991.
[27] D. Mohan, V.N. Singh, S.N. Kaul and Y.C. Sharma, "Removal of lissamine red from wastewater using waste materials," Int. J. Environ. Stud., vol. 59, pp. 115-124, 2002.

[28] S. Rai, S.H. Hasan, M.S.N. Swami, D.C. Rupainwar and Y.C. Sharma, "Removal of cadmium from wastewater by water hyacinth,” Int. J. Environ. Stud., vol. 70, pp. 131-137, 1993.

Received: October 02, 2008

(C) Singh et al.; Licensee Bentham Open.

This is an open access article licensed under the terms of the Creative Commons Attribution Non-Commercial License (http://creativecommons.org/licenses/by-nc/3.0/) which permits unrestricted, non-commercial use, distribution and reproduction in any medium, provided the work is properly cited. 